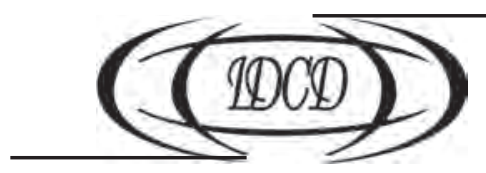

doi: $10.15407 /$ dse2016.02.195

УДК 314.728

JEL Classification: R 23

\title{
I.O. МOCTOBA
}

канд. геогр. наук, наук. співроб.

Інститут демографії та соціальних досліджень імені М.В. Птухи НАН України

01032, Україна, Київ-32, бул. Т. Шевченка, 60

E-mail: mostovajairina@yandex.ru

\section{ДЕЯКІ ПАРАМЕТРИ МІГРАЦІЙНОГО РУХУ НАСЕЛЕННЯ УКРАЇНИ В 2010-2014 рр.: ДИНАМІКА ЗМІН}

Стаття присвячена аналізу загальної міграційної ситуації в Україні починаючи із 2010 року. Основну увагу приділено виявленню головних відмінностей у параметрах міграційного руху населення (кількість прибулих і вибулих осіб у межсах адміністративних одиниць, сальдо міграцій населення, міграційний оборот, інтенсивність міграційних зв'язків) у період до 2014 року та пізніше. Механічні переміщення населення України характеризуються з точки зору статево-вікової структури та в розрізі регіонів (внутрішньорегіональна, міжрегіональна та зовнішня міграція). Усі адміністративні одиниці держави за показником сальдо міграцій поділено на групи - регіони зі високим міграційним приростом населення, із значним і незначним міграційним приростом та регіони із міграційним скороченням населення. Здійснено оцінку міжрегіональних міграцій населення за допомогою розрахунку коефіцієнта інтенсивності міграційних зв'язків та виявлено регіони Украӥни із найактивнішим обміном населення. Оцінено масштаби внутрішнього переміщення населення починаючи із 2014 року та вказано основні напрями таких переміщень. Охарактеризовано якість офіційних статистичних даних стосовно міграцій населення в Україні та викладено рекомендації щодо удосконалення системи міграційного статистичного обліку.

Ключові слова: міграції населення, вимушена міграція, сальдо міграцій, міграційний оборот, коефіцієнт міжрегіональних зв'язків,внутрішньо переміщені особи, шукачі притулку.

\section{И.А. Мостовая}

канд. геогр. наук, науч. сотруд.

Институт демографии и социальных исследований имени М.В. Птухи НАН Украины

01032, Украина, Киев-32, бул. Тараса Шевченка, 60

E-mail: mostovajairina@yandex.ru

\section{НЕКОТОРЫЕ ПАРАМЕТРЫ МИГРАЦИОННОГО ДВИЖЕНИЯ НАСЕЛЕНИЯ УКРАИНЫ В 2010-2014 ГГ.: ДИНАМИКА ИЗМЕНЕНИЙ}

Статья посвящена анализу общей миграционной ситуации в Украине с 2010 года. Основное внимание уделено выявлению главных различий в параметрах миграционного движения населения (количество прибывших и выбывших лии в пределах административных единии, сальдо миграции населения, миграционный оборот, интенсивность миграционных связей) в период до 2014 года и после. Механические

(C) MOCTOBA I.O., 2016 
перемещения населения Украины охарактеризованы с точки зрения половозрастной структуры и в разрезе регионов (внутрирегиональная, межрегиональная и внешняя миграция). Все административные единицы государства по показателю сальдо миграций разделены на группы - регионы с высоким миграционным приростом населения, со значительным и незначительным миграционным приростом и регионы с миграционным сокращением населения. Осуществлена оценка межрегиональных миграций населения с помощью расчета коэффициента интенсивности миграционных связей и выявлены регионы Украины с активным обменом населения. Оценены масштабы внутреннего перемещения населения начиная с 2014 года, и указаны основные направления таких перемещений. Дана характеристика качества официальных статистических миграционных данных населения Украины и изложены рекомендации по совершенствованию системы миграционного статистического учета.

Ключевые слова: миграции населения, вынужденная миграция, сальдо миграции, миграционный оборот, коэффициент межрегиональных связей, внутренне перемещенные лица, ищущие убежища.

\section{I.O. Mostova}

PhD (Geography), researcher

Ptoukha Institute for Demography and Social Studies of the National Academy of Sciences of Ukraine 01032, Ukraine, Kyiv-32, Taras Shevchenko Blvd., 60 E-mail: mostovajairina@yandex.ru

\section{SOME PARAMETERS OF MIGRATION OF THE POPULATION IN UKRAINE IN 2010-2014: DYNAMICS OF CHANGES}

The article is devoted to the overall migration situation in Ukraine since 2010. The attention in the article is focused on differentiation of the main differences in terms of migration of the population (the number of arrivals and departures of persons within administrative units, net migration of population, migration turnover and the intensity of migration links) until 2014 and after it. Mechanical movements of the population in Ukraine are characterized in terms of gender and age structure and by regional factor (intraregional, interregional and external migration). According to the net migration all administrative units of the state are divided into several groups. They are classified into regions with a high net migration, with significant migration growth, with low migration growth and regions with migration reduction of population. The estimation of interregional migration of population by the calculation intensity of migration links is conducted in the article. Ukrainian regions with most active exchange of population are identified. Scale of the internal displacement since 2014 is estimated and the main directions of movement are demonstrated. The quality of official statistical data on migration of the population in Ukraine is characterized. Recommendations for improving the system of the migration statistics are given.

Key words: migration of population, forced migration, net migration, the migration turnover, the coefficient of interregional links, internally displaced persons, asylum seekers.

Постановка проблеми. В сучасному динамічному світі на різних регіональних рівнях посилились процеси, пов'язані із рухливістю населення. Переміщення осіб через державні кордони або межі адміністративно-територіальних одиниць зі зміною місця проживання значною мірою обумовлені різними причинами: екологічними, економічними, етнічними, політичними тощо. Наслідки економічної та політичної кризи в Україні значно активізували процеси, пов'язані з міжрегіональними та міждержавними міграціями населення. Саме тому перед дослідниками постає важливе завдання - здійснення глибокого ретроспективного аналізу міграцій в Україні задля подальшого виявлення особливостей трансформації соціально-економічного життя суспільства.

Метою даної статті є кількісний та якісний аналіз міграційної ситуації в Україні протягом останніх років та виявлення основних відмінностей у міграціях населення у період до 2014 року та пізніше.

Аналіз останніх досліджень. Сучасні дослідники особливу увагу приділяють аналізу соціально-економічних, політичних та історичних тенденцій міграції. На- 
приклад, дослідженню загальної характеристики міграційних процесів в Україні присвячені праці I.M. Прибиткової (I.M. Pribytkova), M.О. Шульги (M.O. Shulga), М.Д. Романюка (M.D. Romaniuk) та ін. Питання трудової міграції розробляли О.У. Хомра (O.U. Homra), Е.М. Лібанова (Е.M. Libanova), О.В. Позняк (O.V. Pozniak), O.A. Малиновська (O.A. Malynovska), C.I. Пирожков (S.I. Pyrozhkov), I.П. Майданік (I.P. Maidanik) та ін.

Що стосується трудової міграції, то на сьогоднішній день найбільш повна характеристика параметрів трудової міграції наведена у загальнонаціональному вибірковому обстеженні «Зовнішня трудова міграція населення України» (2008 р.) та модульному вибірковому обстеженні з питань трудової міграції в Україні (2012р.), які здійснювалися за підтримки міжнародних організацій та за участі національних державних установ.

Вивчення та аналіз загальної міграційної ситуації в Україні на сучасному етапі ускладнюється багатьма факторами, основними з яких є скасування запланованого на 2013 рік Всеукраїнського перепису населення, анексія АР Крим та початок воєнних дій на Сході України. Зокрема, у публікаціях Т.О. Гнатюк (Т.О. Hnatyuk) «Internally Displaced Persons: A New Challenge For Ukraine» [1] та «Displacement in Modern Ukraine» [2] розглянуто основні характеристики процесу внутрішнього переміщення в Україні. Праця О.В. Купець (O.V. Kupets) «Interregional Migration in Ukraine: Special, Economic and Social Factors» [3] присвячена питанню аналізу міжрегіональних міграційних потоків в Україні у 2008-2012 рр. та виявленню їх детермінант. О.А. Малиновська у досліджені «Українсько-Польський міграційний коридор: особливості та значення» [4] акцентує увагу на зростанні в останні роки інтенсивності транскордонної мобільності на українсько-польському кордоні внаслідокі загострення стосунків між Україною та Росією.

Виклад основного матеріалу. Основним джерелом інформації щодо міграційних процесів в Україні у період 2010-2014 рр. є дані Державної служби статистики України, які формуються на основі інформації про реєстрацію та зняття з реєстрації осіб за місцем проживання. Поточний облік міграції охоплює всю територію країни, виконується за єдиною методикою, проте має свої недоліки. Так, використовуючи його дані треба враховувати, що значна кількість громадян не заявляють офіційно про зміну свого місця проживання, а місцеві органи влади малих міст та сіл часто не зацікавлені у наданні реальної статичної інформації про вибулих до органів статистики. Неякісною є також статистика щодо еміграції та імміграції населення, хоча облік осіб, які в’іхали в Україну, є більш адекватним. Крім того, дані українських державних органів про українських мігрантів не збігаються з відповідними даними країн призначення, а учасників малого прикордонного руху не виокремлюють в загальній статистиці [5]. Також Державна служба статистики не фіксує громадян України, які є прохачами притулку в інших країнах, що значно спотворює відомості про міжнародну міграцію, особливо в останні роки.

Основними параметрами, які характеризують міграційну ситуацію в Україні, є статево-вікова структура мігрантів, їхнє громадянство, а також напрями міграційних потоків. Ці показники Державна служба статистики фіксує шляхом за заповненими особою реєстраційної форми. Вони є набагато «біднішими», ніж, наприклад, відповідні показники реєстраційних форм 1995-2004 pр. де також зазначали національність, освіту тощо.

Починаючи з 2014 р. статистичну інформацію щодо міграцій населення Державна служба статистики України формувала на основі наявних адміністративних даних 
щодо зміни реєстрації постійного місця проживання, але без урахування тимчасово окупованої території Автономної Республіки Крим та міста Севастополь. Починаючи iз 2015 р. така інформація надається ще й без урахування зони проведення антитерористичної операції. Міграційна статистика АР Крим є доступною на офіційному статистичному сайті Республіки, а дані щодо механічних переміщень населення 3 окупованих територій Донбасу є вельми примарними. Отже, за допомогою офіційних статистичних відомостей можна охарактеризувати загальні тенденції міграцій населення України та визначити їх параметри, проте до обсягів міграційних переміщень, обрахованих відповідно даних статистичних показників, потрібно ставитися із застереженням, оскільки в сучасних умовах існує проблема їх недообліку, особливо що стосується внутрішньої міграції до регіонів, які «притягують» населення, та виїздів громадян за кордон.

У 2010-2013 рр. міграційний оборот населення України загалом залишався в межах 4,3 млн осіб. Найбільша кількість населення змінила своє місце проживання у 2012 році (1,4 млн осіб). У регіональному розрізі наймобільнішими були жителі Донецької, Дніпропетровської, Харківської областей та Києва, міграційний оборот яких, в середньому за ретроспективний період, становив відповідно 109,0 тис., 93,2 тис., 89,0 тис. та 92,0 тис. осіб. Найменш активним в міграційному плані було населення міста Севастополь (9,3 тис. осіб за 2010-2013 рр.). Відносно висока інтенсивність міграцій була притаманна Вінницькій, Луганській, Львівській та Одеській областям.

Варто зазначити, що до 2014 р. спостерігалася тенденція до незначного скорочення міграційних переміщень населення. Так, у 2013 р. загальна міграційна активність знизилась на 2,3 відсоткових пункти порівняно із 2010 роком. Водночас спостерігалася активізація (на 2,4 \%) міждержавних переміщень і міжрегіональної міграції (на $1,5 \%$ ) та зменшення на 3,9 \% частки населення у внутрішньорегіональних міграціях.

Загалом міграційне сальдо населення України у 2010 р. становило 0,4 \%о, а у 2013 - 0,7 \%о. Тобто, до 2014 р. спостерігалася тенденція до незначного збільшення чисельності населення держави за рахунок міграційних процесів. Міграційний приріст населення (185,1 тис. осіб) формувався внаслідок міграційних потоків як 3 країн СНД (115,9 тис. осіб), так і з інших країн (69,2 тис. осіб). Найбільший міграційний приріст населення спостерігався за рахунок мігрантів із Російської Федерації (59,1 тис. осіб), Молдови (14,5 тис. осіб), Туркменістану (12,3 тис. осіб), Узбекистану (9,2 тис. осіб), Азербайджану (8,2 тис. осіб) тощо.

За чотирирічний період внаслідок зовнішніх міграцій Україну полишило майже 66,0 тис. осіб, з яких 45,8 тис. мали українське громадянство. Натомість близько 193,0 тис. осіб в’їхали до країни, серед яких 148,9 тис. осіб були громадянами інших країн. Зокрема, найбільша кількість населення залишила Дніпропетровську, Донецьку, Луганську, Одеську, Харківську області та місто Київ, а найменша - Тернопільську, Закарпатську, Хмельницьку, Рівненську, Сумську та Волинську області. Міжнародні мігранти, в свою чергу, оселялися переважно в найбільш перспективних регіонах України - м. Київ, Харківській, Одеській, Дніпропетровській, Донецькій областях та АР Крим. Таким чином, коефіцієнт сальдо зовнішньої міграції за регіонами України у 2010 р. варіювався від 1,6\%о у м. Севастополь та 1,2 \%о у АР Крим до -0,1 \%о у Закарпатській області. Наприкінці 2013 р. ситуація майже не змінилася, і максимальне сальдо було у місті Севастополь (2,3 \%o) та АР Крим (2,2 \%о), а найнижче - в Закарпатській області $(-0,3 \%$ \%). 
Натомість міграційний відтік населення спрямовувався, в основному, до європейських країн (у з 2010-2013 pp. 35,8 тис. осіб виїхало до Польщі, Німеччини, Іспанії, Італії, Болгарії тощо) та Російської Федерації (21,1 тис. осіб). Якщо говорити про міжнародну міграцію власне громадян України, то кількість вибулих українців у цей період переважає кількість прибулих на 1,8 тис. осіб, тобто відбувається міграційне скорочення.

Загалом у період з 2010 до 2014 р. кількість іноземців, які в’їжджали в Україну, перевищувала кількість тих, які з неї виїжджали. За ретроспективний період найвищий міграційний приріст іноземних громадян був у 2012 р. і становив 61,2 тис. осіб, для порівняння - у 2010 р. цей показник становив 16,2 тис. осіб. Серед прибулих іноземців найчисельніший контингент складають вихідці із Російської Федерації, Туркменістану та Азербайджану. Кількість прибулих іноземних громадян у 2014 р. знизилася на 20,0 \% у порівнянні із попереднім роком, а кількість вибулих, навпаки, збільшилася на 3,5\%.

Тенденцію зростання кількості іноземних громадян в Україні до 2014 року можна пояснити навчальною міграцією молоді, про що також свідчать дані Міністерства освіти і науки України щодо кількості іноземних студентів в українських ВН3 [6]. Таким чином, у 2011-2012 навчальному році у закладах України навчалося 53,6 тис. студентів-іноземців, у 2012-2013 - 60,5 тис. осіб, у 2013-2014 - 70,0 тис. осіб та у 2014-2015 - 63,2 тис. осіб.

У розрізі типів поселень міграційний приріст за рахунок зовнішніх потоків переважав у містах. Так, у 2010 р. до міських населених пунктів прибуло 23,1 тис. осіб, а до сільських - 7,6 тис. осіб, в 2011 р. - 24,0 тис. та 7,8 тис. осіб відповідно, в 2012 - 68,0 тис. та 8,4 тис. осіб та в 2013 р. - 46,3 тис. та 7,8 тис. осіб.

Регіони України за середнім показником сальдо міграцій населення (за всіма потоками) протягом 2010-2013 рр. поділялися на чотири групи:

- регіони із високим міграційним приростом населення - Київська область, міста Київ і Севастополь;

- регіони зі значним міграційним приростом - Харківська, Одеська області та АР Крим;

- регіони із незначним міграційним приростом - Волинська, Івано-Франківська, Чернівецька, Полтавська, Дніпропетровська області;

- регіони із міграційним скороченням населення - Вінницька, Донецька, Житомирська, Закарпатська, Запорізька, Кіровоградська, Луганська, Львівська, Миколаївська, Рівненська, Сумська, Тернопільська, Херсонська, Хмельницька, Черкаська та Чернігівська області (рис. 1).

Отже, основними донорами мігрантів для інших регіонів України і світу були Вінницька, Донецька, Закарпатська, Кіровоградська, Луганська, Миколаївська, Рівненська, Сумська, Херсонська, Хмельницька, Черкаська та Чернігівська області.

Різні статево-вікові групи населення неоднаково беруть участь у міграційних процесах. Так, основна частина переїздів припадає на учбову та шлюбну міграцію: у контексті міграції саме молоді люди визнані однією з найбільш мобільних соціальних груп. Досягаючи 40 років і більше чоловіки і жінки менше беруть участь у різних територіальних переміщеннях, хоча до 60-річного віку їхня активність залишається порівняно високою. Потрібно зазначити, що у 2013 р., на відміну від 2010, міграційна активність жінок зросла на 3,1 відсоткових пункти, а міграційна активність чоловіків лише на 1,3 . 


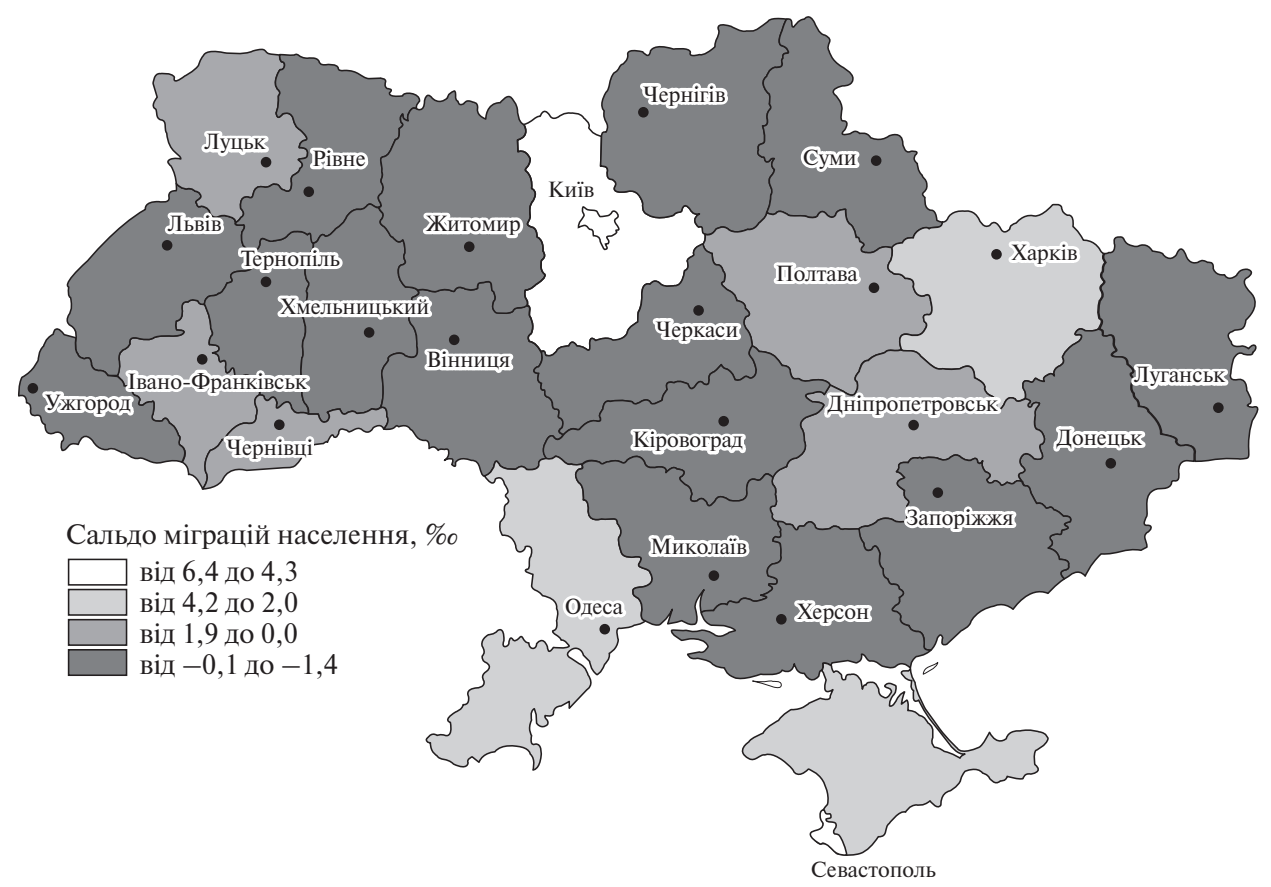

Рис. 1. Середні показники сальдо міграцій населення України в регіональному розрізі у 2010-2013 роках

Джерело: складено автором на основі [7].

Особливістю міграційного руху молодого населення України є його орієнтація на високорозвинені регіони, а основним напрямом залишається переміщення населення з регіональної периферії до обласних центрів та їхніх приміських зон. Така тенденція не лише зумовлює демографічні диспропорції, зокрема старіння населення, в сільській місцевості та малих містах, а й пришвидшує процеси депопуляції окремих територій.

Необхідно вказати, що у загальному міграційному обороті молоді більша частка належить жінкам і становить $34,2 \%$ серед мігрантів усіх вікових груп та 55,8 \% серед молодих мігрантів. Починаючи з 25-річного віку інтенсивність міграційних процесів чоловіків і жінок поступово зрівнюється.

Крім того, у загальному міграційному обороті досить висока частка молодих осіб задіяна саме в міжрегіональній міграції та міграції до інших країн, що відбувається через необхідність навчання та працевлаштування. Загалом у внутрішніх міграційних потоках бере участь 89,7 \% молоді, яка мігрує, тоді як 10,3 \% надають перевагу міжнародній міграції. Потрібно підкреслити, що порівняно із 2010 р. у 2013 зовнішня міграційна активність молодих осіб збільшилася на 5,3 відсоткових пункти, оскільки тенденція до навчання і працевлаштування молодих спеціалістів за кордоном щорічно зростає.

У поселенському аспекті у 2013 р. у містах країни спостерігався міграційний приріст у межах $1,3 \%$, а в селах - міграційне скорочення населення $(-0,6 \%)$. Структура міграційних потоків свідчить, що внутрішньорегіональні переміщення людей складають більше половини всіх міграцій в Україні, а основним типом міграційного руху залишається перерозподіл населення між сільською місцевістю і міськими по- 
селеннями в межах конкретного регіону (області, району тощо). У 2013 р. 155,8 тис. мешканців сіл покинули своє постійне місце проживання та переїхали до міських поселень, зумовивши при цьому вказане вище від’ємне міграційне сальдо у сільській місцевості, та піднявши його у містах та смт.

Загалом, у внутрішньорегіональних міграційних переміщеннях активну участь беруть жінки (57,0 \%), тоді як частка чоловіків найвища у міжнародних міграціях (62,3 та 71,7 \% відповідно). 3 цього можна зробити висновок, що зі збільшенням відстані міграційного пересування збільшується частка чоловіків та відповідно зменшується частка жінок-мігрантів.

Протягом 2010-2013 рр. лідерами за внутрішньорегіональними переміщеннями населення стабільно залишалися Вінницька, Волинська, Житомирська, Полтавська, Рівненська, Сумська та Хмельницька області, коефіцієнти прибуття та вибуття яких знаходилися в межах 10,1-12,8\%о.

Інтенсивне скорочення сільського населення характерне для Кіровоградської, Луганської та Миколаївської областей: враховуючи критичну ситуацію на локальних ринках праці цих регіонів їх жителі виїжджають до більш розвинутих в економічному плані сусідніх агломерацій (Одеса, Дніпропетровськ, Харків тощо). Катастрофічною ситуація в цих регіонах залишається і сьогодні. Навпаки, додатне міграційне сальдо в сільських поселеннях за досліджуваний період зберігали АР Крим і місто Севастополь, Дніпропетровська, Одеська та Черкаська, Київська та Львівська області.

Основним партнером для міжнародного обміну сільським населенням для областей сходу України була Російська Федерація, представники сільського населення західних областей виїжджали переважно до країн Європи (Італія, Чехія, Польща, Угорщина), представники півночі - до Російської Федерації, Італії та Іспанії, а півдня - до Польщі та Італії. Жителі сіл центральної України у своїх міграційних вподобаннях надавали перевагу Чехії, Польщі, Португалії тощо.

Міжрегіональні міграційні потоки спрямовані, в основному, до найбільш економічно розвинутих регіонів України, які володіють високим інноваційним та науковим потенціалом (Київська, Харківська, Дніпропетровська, Одеська області тощо).

Для оцінки міжрегіональних міграцій були розраховані коефіцієнти інтенсивності міграційних зв’язків (КІМЗ) регіонів України, які визначаються за формулою:

$$
K^{i j}=\frac{M^{i j}}{\sum_{i=1}^{n} M^{i j}}: \frac{P^{i}}{\sum_{i=1}^{n} P^{i}},
$$

де $K^{i j}$ - коефіцієнт інтенсивності міграційних зв'язків $j$-того району вселення з $i$ тим районом виходу, $n$ - кількість районів виходу (без району вселення), $M^{i j}-$ об'єм потоку міграції з $i$-того регіону до $j$-того, $P^{i}-$ середньорічна чисельність населення регіону [8].

Діапазон даного показника варіював у межах від 0,0 до 14,6. Найсильніші міграційні зв'язки «регіон-столиця» мали з Києвом Київська, Житомирська, Черкаська та Чернігівська області, коефіцієнт інтенсивності яких був вищим за 2,0. Відносно інтенсивні міграційні зв'язки у 2013 р. були між столицею України і Вінницькою, Кіровоградською, Полтавською, Рівненською, Сумською та Хмельницькою областями $(1,1-1,9)$. Натомість найслабші зв’язки в міграційному плані спостерігалися між столицею та АР Крим, Донецькою, Закарпатською, Івано-Франківською, Львівською, Одеською, Харківською та Чернівецькою областями (менше 0,5). 
Розрахунки показали, що найактивніший обмін населенням відбувається між сусідніми областями. Найтісніший зв'язок наприкінці 2013 р. був між АР Крим та м. Севастополь (14,6-9,3), Київською областю та м. Київ $(6,5-4,5)$, Волинською та Рівненською областями $(8,7-6,5)$, Чернівецькою та Івано-Франківською областями $(6,9-6,5)$.

Середні показники інтенсивності міграційних зв’язків у межах від 4,5 до 1,0 встановилися між АР Крим та Херсонською областю, між Вінницькою, Житомирською та Київською областями, Волинською та Львівською областю, Дніпропетровською та Кіровоградською і Запорізькою областями, а також між Донецькою, Луганською та Харківською областями тощо.

Найслабші зв’язки були між східними та західними областями, що можна пояснити їх географічним положенням, транспортною доступністю та особливостями менталітету. Зокрема, найнижчі коефіцієнти в межах від 0,0 до 0,5 були притаманні Волинській, Закарпатській, Івано-Франківській, Львівській, Рівненській, Тернопільській та Чернівецькій областям, з однієї сторони, та АР Крим, Дніпропетровській, Донецькій, Луганській, Запорізькій, Сумській, Одеській та Харківській областям, з іншої.

Міграційна ситуація населення України у 2014-2015 рр. зазнала деяких змін внаслідок політичної та економічної кризи, окупації АР Крим та проведення антитерористичної операції АТО на Сході України. Таким чином, необхідно говорити про певний перерозподіл внутрішньодержавних міграційний потоків (як внутрішньорегіональних, так і міжрегіональних), а також про зміни в обсягах зовнішніх міграцій.

За даними Державної служби статистики України [7], міграційний оборот населення України у 2014 р. становив майже 1,1 млн. осіб, а загальний міграційний приріст - 0,5\%о. Так, 54,3 тис. мігрантів прибули до нашої держави у цей період та 51,2 тис. виїхали 3 неї ${ }^{1}$ Міграційний приріст у цьому році формувався в основному за рахунок іноземних громадян (у т. ч. освітня міграція), а якщо говорити про власне громадян України, то у 2014 р. було міграційне скорочення, оскільки 8,6 тис. осіб виїхало з України та 5,1 тис. осіб в’їхали в Україну.

У 2014 р. міграційний приріст України формувався переважно за рахунок притоку населення з Російської Федерації (14,8 тис. прибулих), Молдови (2,6 тис. прибулих), Туркменістану (2,5 тис. прибулих), Узбекистану (1,4 тис. прибулих) та Азербайджану (2,3 тис. прибулих). Зокрема, необхідно зазначити, що кількість прибулих із Російської Федерації знизилася на 25,0 \% у 2014 р. порівняно з 2013 р., а кількість вибулих - на 28,1\%. Загалом же міграційний приріст населення України в абсолютних показниках у 2014 р. становив 22,6 тис. осіб.

У 2014 р. основними країнами, що приймали осіб, які виїхали з України, були країни Свропи (4,3 тис. осіб), особливо Німеччина (1,3 тис. осіб), Угорщина (847 осіб) та Польща (589 осіб). Значна кількість людей виїхала також до Російської Федерації (3,5 тис. осіб) та Туркменістану (1,8 тис. осіб).

У регіональному розрізі додатний міграційний баланс спостерігався в межах Вінницької, Волинської, Дніпропетровської, Івано-Франківської, Київської, Львівської, Миколаївської, Одеської, Полтавської, Тернопільської, Харківської, Хмельницької, Черкаської Чернівецької області та Києві. Натомість Донецька, Житомирська, Закарпатська, Запорізька, Кіровоградська, Луганська, Рівненська, Сумська, Херсонська та Чернігівська області втрачали населення. Серед останніх

1 Без урахування тимчасово окупованої території Автономної Республіки Крим і м. Севастополь, дані щодо Донецькіої та Луганської областей є неповними. 
найбільше міграційне скорочення населення було характерне для Донецької $(-10,7$ тис. осіб), Луганської ( $-8,1$ тис. осіб) $)^{2}$, Закарпатської ( $-0,8$ тис. осіб) та Херсонської $(-0,9$ тис. осіб) областей.

У поселенському розрізі у 2014 р. до міських населених пунктів прибуло 36,2 тис. осіб, а до сільських - 6,5 тис. осіб. Крім того, у містах та селах країни спостерігався міграційний приріст у межах $0,1 \%$ о та 0,2\%о відповідно. Тобто у 2014 р. міграційне сальдо сільської місцевості набуло додатніх значень, а в 2013 р. воно було від’ємним.

Відповідно до коефіцієнта інтенсивності міжрегіональних зв'язків, пожвавлення міжрегіональних переміщень у 2014 році відбулися між Донецькою і Луганською областями та майже усіма іншими регіонами держави. Зокрема, КIMЗ значно зріс між Донецькою областю та Одеською (на 0,4 од.), Сумською (на 0,3 од.) і Харківською областями (на 0,3 од.), між Луганською та Дніпропетровською (на 0,5 од.), між Одеською (на 0,7 од.), Полтавською (на 0,3 од.), Сумською (на 0,6 од.), Тернопільською (на 0,6 од.), Харківською (на 0,8 од.) та Черкаською областями (на 0,6 од.). Проте між власне Донецькою та Луганською областями у 2014 р. значно послабшали міжрегіональні зв'язки: порівняно із 2013 р. КІМЗ між ними знизився на 75,0 \%.

Загалом же, варто відмітити незначне послабшання міжрегіональних зв'язків між сусідніми регіонами та, загалом, між іншими регіонами України у 2014 р., порівняно із 2013 р. Крім того, у 2014 р. обмін населенням між столицею України та Донецькою, Харківською, Херсонською, Чернігівською областями залишався на тому ж рівні, що і в 2013 р., тоді як населення інших регіонів України дещо менше стало приїздити до Києва і навпаки.

У 2014 р. внутрішньорегіональна міграція становила 51,5\% від усіх міграційних переміщень у країні. Загалом усі регіони України, крім Рівненської області, у 2014 p. характеризувалися зниженням інтенсивності внутрішньої міграції порівняно із 2013 р. Наприклад, населення Вінницької області стало менше здійснювати переміщення всередині регіону на $14,3 \%$, Волинської - на $14,4 \%$, Житомирської - на $17,0 \%$, Полтавської - на 10,4 \%, Сумської - на 9,8 \% і лише населення Рівненської області у 2014 р. на $0,4 \%$ стало частіше переїздити до інших населених пунктів свого регіону. Відмітимо також стрімке зниження внутрішньорегіональних потоків у межах Луганської (на 64,5 \%), Донецької (на 45,2 \%), Харківської (на 20,8 \%) та Запорізької областей (на 20,4\%).

Міграційний приріст АР Крим у 2014 р. становив 1,5 тис. осіб або 0,8 \%о і формувався переважно за рахунок прибулого населення з Росії та інших країн СНД. 3 території материкової України до АР Крим у 2014 р. приїхало майже 15,0 тис. осіб, а виїхало 13,5 тис., сформувавши при цьому додатній міграційний приріст (1,5 тис. осіб). Найбільша кількість осіб прибула з Дніпропетровської (1,1 тис. осіб), Миколаївської (1,3 тис. осіб), Одеської (1,6 тис. осіб), Херсонської (1,0 тис. осіб) областей та Києва ( 2,8 тис. осіб). Населення із АР Крим у цьому році найбільше виїхало до Дніпропетровської (1,6 тис. осіб), Донецької (2,1 тис. осіб), Запорізької (1,4 тис. осіб), Харківської (1,8 тис. осіб), Херсонської (1,5 тис. осіб) областей та Києва (1,2 тис. осіб).

Статево-вікова структура мігрантів України у 2014 р. зображена на рис. 2. Як і раніше, основна частина населення, задіяна у міграціях, - це молоді люди віком від 15 до 35 років. Групи осіб віком 15-19 років та 20-24 роки найбільше були залучені до міграційних процесів (в основному освітня міграція), i їхня частка становила відповідно $22,7 \%$ та 21,6\%.

\footnotetext{
2 Дані можуть бути не точними.
} 


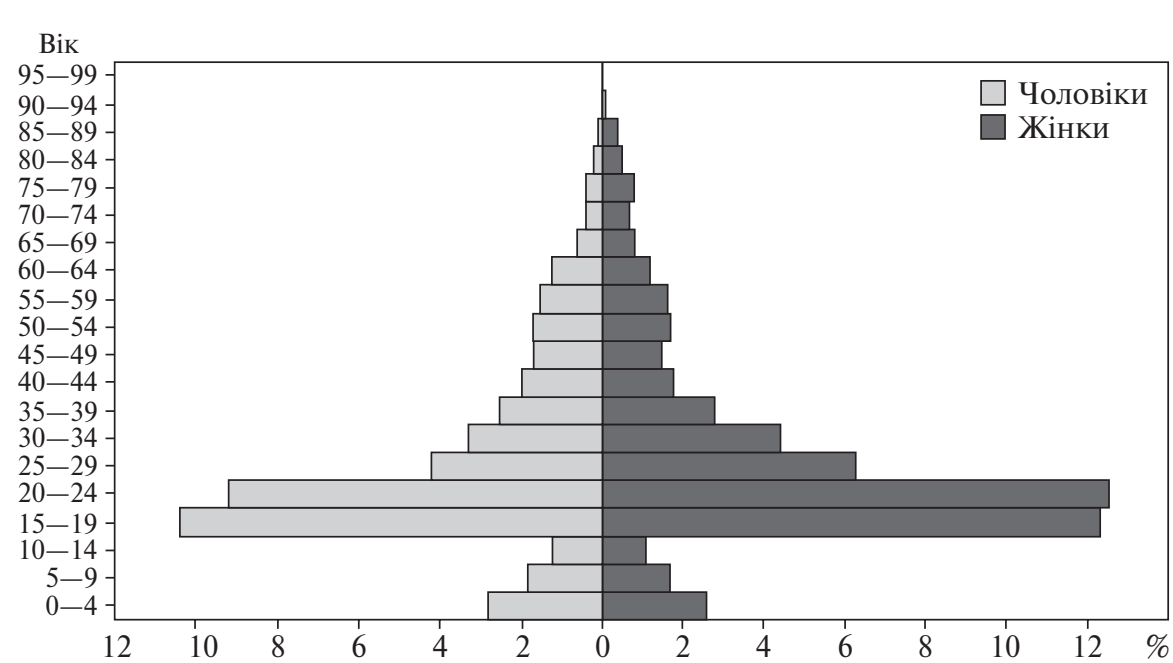

Рис. 2. Статево-вікова піраміда мігрантів в Україні у 2014 році (усі потоки), \%

Джерело: складено автором на основі [7].

Дещо менше залучені до територіальних переміщень молоді особи у віці 25-29 $(10,5 \%)$ та $30-34$ років $(7,7 \%)$. Серед молодого населення активніше змінювали своє місце проживання жінки (35,5 \% серед загального міграційного обороту), ніж чоловіки $(27,1 \%)$. Відповідно зі зростанням віку мігрантів знижується й їхня міграційна активність, однак категорія людей у віці 35-39 років, 40-44 та 50-54 років зберігає відносно високу міграційну активність $(2,8 \%, 1,8 \%$ та 1,7 \%).

Згідно з оперативною інформацією Міжвідомчого координаційного штабу з питань соціального забезпечення громадян України, які переміщуються з районів проведення антитерористичної операції та тимчасово окупованої території (МКШ), створеною при Державній службі з питань надзвичайних ситуацій, з тимчасово окупованої території та районів проведення АТО до інших регіонів станом на 17 вересня 2015 р. переселено 949 тис. 631 особу, у тому числі з Донецької, Луганської областей - 928 тис. 702 особи та з Автономної Республіки Крим та міста Севастополь 20 тис. 929 осіб. Ці дані є офіційними, але, на жаль, дуже приблизними через неможливість точного підрахунку в умовах збройного конфлікту [9].

Найбільшими регіонами-приймачами внутрішньо переміщених осіб (ВПО) стали Харківська (190,4 тис. осіб), Луганська (220,9 тис. осіб), Донецька (113,1 тис. осіб), Дніпропетровська (84,5 тис. осіб), Запорізька (65,7 тис. осіб), Київська (43,6 тис. осіб) області та м. Київ (39,1 тис. осіб). Найменшу кількість переселенців розселено у Тернопільській $(3,0$ тис. осіб), Чернівецькій $(2,7)$, Івано-Франківській $(3,6)$, Закарпатській $(4,0)$, Волинській $(4,2)$ та Рівненській $(3,5)$ областях.

Облік ВПО (крім МКШ) веде Міністерство соціальної політики України. При цьому МКШ фіксує осіб, які звернулися по допомогу в переселенні та розміщенні, а Мінсоцполітики обліковує осіб, які звернулися з питань виплати належної їм пенсії або соціальної допомоги за новим місцем проживання. В реальності облік Мінсоцполітики охоплює не лише переселенців, але й тих, хто фактично живе на окупованій території та періодично приїздить для отримання пенсії чи соціальної допомоги на контрольовані центральною владою території (т. зв. пенсійний туризм). Динаміка кількості ВПО у період із червня 2014 до 2015 року за даними Мінсоцполітики зображена на рис. 3. 


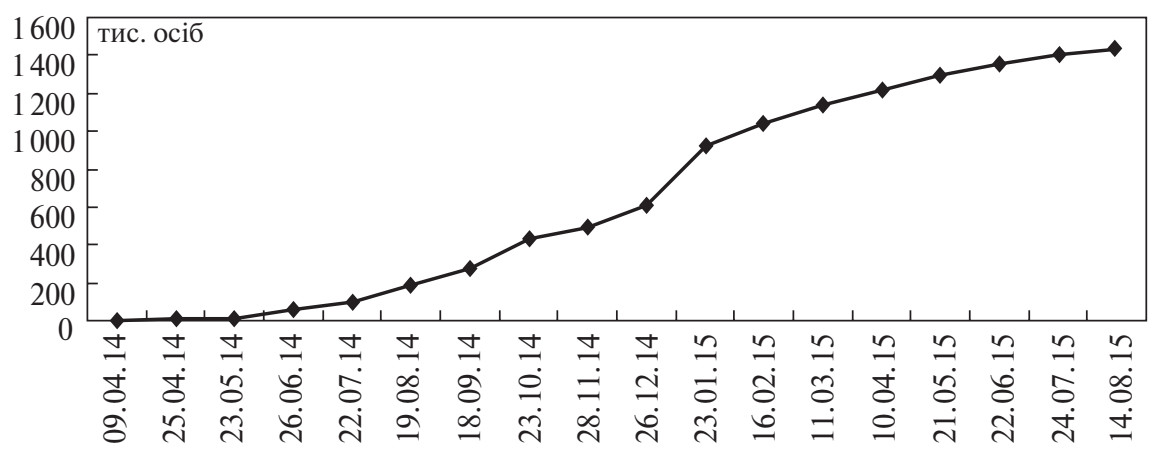

Рис. 3. Динаміка загальної кількості внутрішньо переміщених осіб в Україні з окупованої АР Крим та територій АТО у період із 9 квітня 2014 року до 14 серпня 2015 року

Джерело: складено автором на основі [10].

Таблиця 1. Характеристика українських ВПО, \%

\begin{tabular}{|l|c|c|}
\hline \multicolumn{1}{|c|}{ Категорія } & Донбас & Крим \\
\hline Жінки працездатного віку (18-55) & 35,1 & 31,4 \\
\hline Чоловіки працездатного віку (18-60) & 12,8 & 19,7 \\
\hline Мігранти пенсійного віку $(55+/ 60+)$ & 19,1 & 21,3 \\
\hline Діти $(0-18)$ & 33,0 & 27,6 \\
\hline
\end{tabular}

Джерело: складено авторомна основі [11].

Кількість населення працездатного віку серед ВПО (а це, зазвичай, працюючі особи) складає приблизно 50,0 \% від загальної кількості мігрантів з Криму та зони АТО (табл. 1). Але через брак даних про переселенців зробити однозначні висновки щодо реального обсягу трудової міграції зі Сходу та Півдня України важко.

Відповідно до офіційних даних Євростату [12], протягом 2014-2015 pp. 34380 українців попросили притулок у країнах СС. До п’ятірки «найпопулярніших» країн увійшли Німеччина (7225 осіб), Італія (6755 осіб), Іспанія (4230 осіб), Франція (3020 осіб) та Польща (3725 осіб), проте вони надавати цей статус не поспішають. Так, найбільшу кількість відмов українці отримали в Польщі (1770 рішень про відмову у 2015 р.) та Франції (1310 рішень у 2015 р.). Основною аргументацією є можливість переїхати до іншої частини країни та почуватися там у безпеці.

Найбільша кількість українців звернулися за статусом біженця та тимчасовим притулком саме до Російської Федерації, що зумовлено близькістю і протяжністю державного кордону, схожим менталітетом, відсутністю мовних бар'єрів, наявністю численних родинних зв’язків тощо. Так, у 2014 р. до РФ за статусом біженця та тимчасовим притулком звернулися 271237 громадян України, а у 2015 р. таких осіб було 129 580. Рівень задоволення заяв при цьому склав майже 95,0 \% [13].

Висновки. Отже, згідно з інформацією Державної служби статистики, міграційний оборот населення України у 2014 р. становив 84,6 \% від даного показника 2013 р. Зокрема, показник внутрішньорегіональної міграції знизився на 24,0 \%, міжрегіональної - на 19,3 \% та міждержавної міграції - на 15,7 \%. Проте, за умов збройного конфлікту, офіційні статистичні дані не зовсім реалістично відображають міграційну 
ситуацію в країні, оскільки масштаб внутрішніх та зовнішніх міграцій починаючи з 2014 р. є набагато більшим: 1) існують труднощі із реєстрацією переселенців; 2) багато пенсіонерів реєструються як вимушені переселенці, щоб мати змогу отримувати пенсію, а потім знову повертаються до окупованої території або сусідніх країн; 3) чоловіки призовного віку часто не реєструються як ВПО з метою не потрапити до служби у Збройних силах України; 4) деякі ВПО після отримання статусу через фінансові труднощі знову повертаються до території колишнього проживання; 5) особи, які є фінансово забезпеченими, не завжди прагнуть отримати статус ВПО.

За цих умов досить важливим є питання удосконалення нинішньої системи міграційного обліку. Основні рекомендації щодо цього такі: необхідно запровадити чітку систему реєстрації ВПО; поліпшити міжвідомчу взаємодію державних органів влади у сфері збору, зберігання та поширення інформації щодо міграцій та вимушених переміщень; проводити регулярні обстеження трудової міграції українців за кордон; Державній службі статистики удосконалити реєстраційні форми тощо. Проте найнеобхіднішими кроками сьогодні є проведення Другого Всеукраїнського перепису населення та створення Сдиного державного демографічного реєстру.

\section{ЛІТЕРАТУРА}

1. Hnatyuk T.O. Internally Displaced Persons: A New Challenge For Ukraine // Demography and social economy. - 2014. - №2 (22). - C. 187-197. doi: 10.15407/dse2014.02.187

2. Hnatyuk T.O. Displacement in Modern Ukraine // Newsletter of Global Research Forum on Diaspora and Transnationalism, New Delhi, India. - 2015. - September-October. - Vol. 4. - \# P.9-10.

3. Kupets O.V. Interregional Migration in Ukraine: Special, Economic and Social Factors // Demography and social economy. - 2014. - № 2 (22). - C. 164-175. doi: 10.15407/dse2014.02.164

4. Малиновська О.А. Українсько-Польський міграційний коридор: особливості та значення // Демографія та соціальна економіка. - 2015. - № 2 (24). - С. 31-40. doi: 10.15407/dse2014.02.176

5. O. Poznyak, O. Malynovska. An Assessment of the Collection, Distribution, Storage and Analysis of Migration Information in Ukraine / Strengthening Migration Management and Cooperation on Readmission in Eastern Europe. International Organization for Migration. - Kiev, 2015. - 76 p.

6. Український державний центр міжнародної освіти. Міністерство освіти і науки України [Електронний ресурс]. - Режим доступу: http://intered.com.ua/

7. Державна служба статистики України [Електронний ресурс]. - Режим доступу: http://www. ukrstat.gov.ua

8. Рыбаковський Л.Л. Региональный анализ миграций. - М. : Статистика. - 1973. - 159 с.

9. Міністерство з надзвичайних ситуацій [Електронний ресурc]. - Режим доступу - http://www. mns.gov.ua/news/34232.html

10. Міністерство соціальної політики [Електронний ресурс]. - Режим доступу: http://www.mlsp. gov.ua/labour/control/uk/index

11. У пошуках мирного неба [Електронний ресурс] / Forbes Україна. - Режим доступу : http://forbes. ua/ua/opinions/1376760-u-poshukah-mirnogo-neba

12. Eurostat [Електронний ресурс]. - Режим доступу: http://ec.europa.eu/eurostat

13. Федеральная миграционная служба Российской Федерации [Електронний ресурс]. - Режим доступа: https://www.fms.gov.ru/

\section{REFERENCES}

1. Hnatyuk, T.O. (2014). Internally Displaced Persons: A New Challenge For Ukraine. Demography and social economy, 2(22), 187-197 [in English]. doi: 10.15407/dse2014.02.187

2. Hnatyuk, T.O. (2015). Displacement in Modern Ukraine. Newsletter of Global Research Forum on Diaspora and Transnationalism, 4, 9-10. New Delhi, India [in English]. 
3. Kupets, O.V. (2014). Interregional Migration in Ukraine: Special, Economic and Social Factors. Demography and social economy, 2(22), 164-175 [in English]. doi: 10.15407/dse2014.02.164

4. Malynovska, O.A. (2015). Ukrainsko-Polskyi mihratsiinyi korydor: osoblyvosti ta znachennia [Ukrainian-Polish migration corridor: features and importance]. Demohrafiia ta sotsialna ekonomika - Demography and social economy, 2(24), 31-40 [in Ukrainian]. doi: 10.15407/dse2014.02.176

5. Poznyak, O. \& Malynovska, O. (2015). An Assessment of the Collection, Distribution, Storage and Analysis of Migration Information in Ukraine. Strengthening Migration Management and Cooperation on Readmission in Eastern Europe. Kiev : International Organization for Migration [in English].

6. Ukrainskiy derzhavniy tsentr mizhnarodnoi osvity. Ministerstvo osvity i nauky Ukrainy [Ukrainian State Center of International Education. Ministry of Education and Science of Ukraine]. intered.com. ua. Retrieved from http://intered.com.ua/ [in Ukrainian].

7. Derzhavna slugba statystyky Ukrayiny [Site Statistic Service of Ukraine]. ukrstat.gov.ua. Retrieved from http://www.ukrstat.gov.ua [in Ukrainian].

8. Rybakovskyi, L.L. (1973). Rehyonalnyi analyz myhratsyi [Regional analyze of migrations]. Moskva : Statystyka. [in Russian].

9. Ministerstvo z nadzvychainykh sytuatsii Ukrainy [State Emergency Service of Ukraine]. mns.gov.ua. Retrieved from http://www.mns.gov.ua/ [in Ukrainian].

10. Ministerstvo sotsial'noyi polityky Ukrayiny [The UN Refugee Agency]. mlsp.gov.ua. Retrieved from http://www.mlsp.gov.ua/labour/control/uk/index [in Ukrainian].

11. U poshukakh myrnoho neba [In search of a peaceful heaven]. Forbes Ukraina - Forbes Ukraine. forbes.net.ua. Retrieved from http://forbes.net.ua/ua/opinions/1376760-u-poshukah-mirnogo-neba [in Ukrainian].

12. Eurostat. Retrieved from http://ec.europa.eu/eurostat [in English].

13. Federal'naja migratsionnaja sluzhba Rossijskoj Federatsii [Federal Migration Service]. Retrieved from https://en.fms.gov.ru/ [in Russian].

Стаття надійшла до редакції журналу 24.03.2016. 